\title{
Hair sheep performance in a mid-stage deciduous Appalachian silvopasture
}

\author{
A. G. Fannon · J. H. Fike 1 - S. P. Greiner $\cdot$ C. M. Feldhake $\cdot$ M. A. Wahlberg
}

Received: 9 April 2017/ Accepted: 3 November 2017/Published online: 17 November 2017

(C) Springer Science+Business Media B.V., part of Springer Nature 2017

\begin{abstract}
Silvopastoral management has potential to diversify and increase the output from livestock systems. Silvopastures offer solutions to many management issues associated with grazing systems in Appalachia (USA). Several tree species have been proposed for silvopastures in humid temperate regions, but few data comparing animal performance from systems with different deciduous tree species are available. The objective of this project was to compare early-stage honeylocust (Gleditsia triacanthos) or black walnut (Juglans nigra) silvopastures with open pastures in terms of forage botanical composition, yield, and nutritive value, and in terms of gain, carcass characteristics, and meat quality of hair sheep (Ovis aries) that grazed these systems. Forage and animal performance from open systems (i.e., no trees) was
\end{abstract}

C. M. Feldhake and M. A. Wahlberg were retired.

A. G. Fannon

Virginia Cooperative Extension, Jonesville, VA, USA

J. H. Fike $(\square)$

Crop and Soil Environmental Sciences, Virginia Tech, Blacksburg, VA, USA

e-mail: jfike@vt.edu

S. P. Greiner · M. A. Wahlberg

Animal and Poultry Sciences, Virginia Tech, Blacksburg, VA, USA

C. M. Feldhake

USDA-ARS, Beaver, WV, USA compared with that from silvopastures containing 13and 14-year-old honeylocust or black walnut trees. Cool-season grass-legume pastures were rotationally stocked with crossbred hair sheep from mid-June through September in 2008 and 2009. Forage production varied by year and pre-graze forage mass in black walnut silvopastures generally was less $(P \leq 0.05)$ than in open pastures at most measurement periods. Averaged over the season, forage production in honeylocust silvopastures tended $(P=0.0937)$ to be lower than in open systems in 2008 and was lower $(P=0.0001)$ in 2009. Few differences in forage nutritive value among systems were observed. Total and average daily gains (ADG) did not differ among treatments in 2008, but black walnut silvopastures supported less $(P \leq 0.05)$ ADG and total gain than open pastures and honeylocust silvopastures in 2009. Carcass characteristics evaluated did not vary among treatments although hot carcass weights were lower $(P<0.05)$ for lambs that grazed black walnut silvopastures. Although walnut-based systems were less productive and will need modification to improve output, similar levels of performance between open pastures and honeylocust systems show the potential of silvopasture systems to supply multiple products from the land base without reducing agricultural system production.

Keywords Black walnut · Honeylocust - Coolseason forage $\cdot$ Carcass characteristics 


\section{Introduction}

The Appalachian region of the USA is characterized by steep topography, often with erosive, low-fertility soils that present challenges to economic viability of farms in the region (Feldhake and Schumann 2005). Although pastures are the typical agricultural land use in Appalachia, silvopastures have potential to improve the region's economic and environmental outcomes. Silvopastures are grazing systems in which trees and forages are integrated and managed on a unit of land (Clason and Sharrow 2000). Along with potential for diversified farm production and increased conservation benefits, silvopastures may increase animal welfare and productivity given the benefits of tree shade in hot, humid environments (McDaniel and Roark 1956), and this is a point of interest among producers (Mayerfeld et al. 2016; Orefice et al. 2017). To date, however, limited knowledge of these systems, their site-specific management requirements, and economic potential (e.g., Mize 2014; Orefice et al. 2016) have constrained adoption of silvopastures.

As producers learn more about these systems, they frequently have questions about forage yield and management. Cool-season forage production in silvopastures can vary markedly depending on a number of factors such as tree and forage species, tree age, planting density and management, and environmental conditions (Fike et al. 2004). One strategy for minimizing competition for light and maintaining forage productivity is to plant trees with compound leaves or trees that develop later in the growing season-or both. Such trees may present less competition for light resources to the forage understory than would some conifer or early-developing, heavyleaved tree species (Fike et al. 2004; DeBruyne et al. 2011).

Forage yield responses in the presence of trees vary markedly in the literature (Buergler et al. 2005; Neel and Belesky 2015; Ford et al. 2017). Greater opportunities to optimize forage production may accrue to planted (as opposed to thinned) silvopastures, given the ability to choose tree species and to apply greater control over tree spacing and spatial arrangement. In some cases, trees may convey yield benefits to the forage understory. In an emulated silvopasture with young (7- to 8-year-old) deciduous trees that leafed out in late spring, cool-season forage yields were increased about $15 \%$ under medium density plantings (about 370 stems ha ${ }^{-1}$; Buergler et al. 2005). Yields of stockpiled forages under stands of 4- and 5-year-old mixed hardwoods did not differ from yields in open pasture systems in a grazing study-although the area available for grazing was reduced due to tree protection needs (Kallenbach et al. 2010). However, yields of annual forages - annual ryegrass (Lolium multiflorum L.) and cereal rye (Secale cereale L.)-were decreased $19 \%$ when grown under a stand of 6- to 7-year-old black walnut and hybrid pitch-loblolly pine (Pinus rigida-P. taeda L.) trees in Missouri, USA (Kallenbach et al. 2006). This was largely because forage growth near the trees was reduced by $40-60 \%$. Tree management is an important factor in maintaining forage production in silvopastures. Tree age, species, spacing (Burner and Brauer 2003) and management (e.g., trimming the bole) all affect the productivity and quality of the understory forage crop.

Although forage production may be reduced in silvopastures, this does not necessarily translate into lower animal performance. Despite $19 \%$ less cumulative forage production and $15 \%$ fewer grazing days in the silvopasture system, no differences in heifer ADG were observed between open and pine-walnut silvopastures (Kallenbach et al. 2006). Both greater forage nutritive value and lower animal stress were considered factors in these results.

The energy sparing effects of trees is likely a key factor in maintaining or improving animal production in silvopastures relative to open pasture systems. Integrating trees into pastures can reduce the energy that otherwise would be required by livestock to maintain homeostasis. Tree shelter can protect animals from hot and cold temperature extremes and from strong winds (McArthur 1991). In a summer study, both cows and calves gained more weight when provided access to natural shade in pastures ( $\mathrm{McDa}-$ niel and Roark 1956). Animals did not spend more time grazing but spent less time standing and more time lying down. This may also translate into better meat quality. Although not a study of silvopastures, heifers in shaded feedlots spent more time lying, displayed fewer agonistic behaviors, and had greater ADG; those animals also had fewer incidents of "dark cutters", a negative carcass quality trait (Mitlöhner et al. 2002).

Forage and animal outputs from silvopastures appear strongly affected by tree species, site conditions, and management (e.g., contrast Peri et al. 2001 
vs. Kallenbach et al. 2006). However, the literature on silvopastures is limited and animal performance comparisons between silvopastures with different tree species are lacking. Thus, this study was performed to measure forage and animal performance in early-stage black walnut and honeylocust silvopastures compared with that of open pasture systems. Our objectives were to determine forage attributes (botanical composition, yield, and nutritive value) and performance responses (gain and carcass quality) of hair sheep that grazed these systems through the summer. Hair sheep were used as the model species for this study as they are of increasing interest to livestock producers given high fecundity, parasite resistance and low input requirements (Wildeus 1997). We hypothesized that forage production, animal gain, and animal carcass characteristics would not differ among the open and silvopasture systems.

\section{Methods and materials}

Field research was conducted at Virginia Tech's Kentland Farm in Blacksburg, VA $\left(37^{\circ} 11^{\prime} \mathrm{N}\right.$ latitude, $80^{\circ} 35^{\prime} \mathrm{W}$ longitude, $545 \mathrm{~m}$ elevation above sea level). Soil series on the site include Berks-Lowell-Rayne complex, Unison and Braddock, and Weaver soils. Soils are primarily fine-textured, mixed mesic, Typic Hapludults and Typic Hapludalfs along with fine loamy mixed mesic Fluvaquentic Eutradepts. The soils generally are well-drained with sloped topography ranging from 10 to $25 \%$, although the soils of the Weaver series (about $20 \%$ of the land area) have 0 to $5 \%$ slope and are moderately well drained. Soils are characterized by moderate permeability and available water capacity, and generally have low organic matter and low inherent fertility.

Plots for this study are part of a larger agroforestry project established in 1995 to research and demonstrate the biological interactions that occur when trees are integrated with agricultural systems. Locust and walnut seedling trees for each silvopasture type were planted in 1995 into the existing cool-season forage base. Trees were planted in rows parallel with the slope at a $2.44-\mathrm{m}$ (within row) $\times 12.2-\mathrm{m}$ (between row) spacing at a density of about 410 stems ha $^{-1}$. Every fifth tree in the honeylocust system was planted with the 'Millwood' variety.
The first eight years following establishment, vegetation around the tree (radius $\sim 1 \mathrm{~m}$ ) was killed with seasonal applications of glyphosate. In spring 2008, prior to the grazing study, $40 \%$ of the trees within each tree row were thinned leaving an average stand density of about 250 stems ha ${ }^{-1}$. Thinning accounted for the in-row arrangement of honeylucst trees. Thus, for each five trees within a row, the second and fourth trees were removed, although this arrangement was sometimes modified in the walnut systems in consideration of tree form.

Experimental treatments and treatment pastures

The three experimental treatments for this study were open pastures, honeylocust silvopastures, and black walnut silvopastures. About a year before tree establishment, the site was planted to orchardgrass (Dactylis glomerata L.) using a no-till drill. Other cool season species such as tall fescue (Festuca arundinacea L., syn. Lolium arundinaceum Darbysh., syn. Schedonorus phonenix (Scop.) Holub.), Kentucky bluegrass (Poa pratensis L.), and red and white clovers (Trifolium pratense L. and T. repens L.) were present from previous use and reappeared in these systems over time. At commencement of the grazing study in 2008, pastures also contained hop clover; ( $T$. campestre Schreb.), sweet vernal grass (Anthoxanthum oderatum L.) and nimblewill (Muhlenbergia schreberi J.F. Gmel.). Forage botanical composition was determined by visual evaluation at the start of the study (2008) similar to Brodie (1985). Forage presence was ranked based on percent cover and converted to a 5 -point scale, with $5=$ dominant and $1=$ rare. Cover assessments were made on each sub-paddock within each pasture.

Weather

Monthly average daytime temperatures were collected with an on-site weather station. Daytime temperatures generally were warmer than the previous 10-year average in 2008, but cooler in 2009 (Table 1). Of the two seasons, insolation was greater in 2008, corresponding with more cloud-free days. Precipitation was similar between years but more evenly distributed in 2009 , which was marked by more moisture and cloudy skies, particularly in the latter part of the study. 
Table 1 Ambient temperatures, precipitation, and insolation at Kentland Farm, Blacksburg, VA USA, during June-September of 2008 and 2009 when lambs grazed open pastures and silvopastures

\begin{tabular}{|c|c|c|c|c|c|c|}
\hline & \multicolumn{2}{|c|}{ Temperature $\left({ }^{\circ} \mathrm{C}\right)$} & \multicolumn{2}{|c|}{ Precipitation $(\mathrm{mm})$} & \multicolumn{2}{|c|}{ Insolation $\left(\mathrm{KW} / \mathrm{m}^{2}\right)$} \\
\hline & $\operatorname{Max}$ & $10 \mathrm{YAM}^{\mathrm{a}}$ & Monthly & $10 \mathrm{YAT}^{\mathrm{b}}$ & Monthly & $10 \mathrm{YAT}^{\mathrm{b}}$ \\
\hline \multicolumn{7}{|l|}{2008} \\
\hline June & 33.6 & 31.3 & 55.6 & 100.9 & 196.0 & 176.9 \\
\hline July & 32.1 & 31.7 & 141.5 & 122.1 & 198.5 & 176.5 \\
\hline Aug & 30.8 & 32.3 & 70.9 & 63.6 & 171.9 & 168.7 \\
\hline Sept & 30.3 & 29.6 & 34.0 & 85.9 & 129.2 & 131.3 \\
\hline \multicolumn{7}{|l|}{2009} \\
\hline June & 30.9 & 31.5 & 91.9 & 96.4 & 194.2 & 178.1 \\
\hline July & 30.5 & 31.8 & 93.7 & 124.1 & 170.9 & 177.3 \\
\hline Aug & 30.7 & 32.1 & 74.4 & 64.3 & 167.6 & 166.9 \\
\hline Sept & 29.2 & 29.7 & 68.8 & 80.7 & 112.9 & 129.2 \\
\hline
\end{tabular}

${ }^{\mathrm{a}} 10 \mathrm{YAM}=$ Previous 10-year average monthly maximum

${ }^{\mathrm{b}} 10 \mathrm{YAT}=$ Previous 10-year average monthly total

Animals, stocking rates, and pasture management

In 2008,50 crossbred lambs (Katahdin $\times$ DorsetFinn-Rambouillet) were blocked by weight $(23.9 \pm 2.99 \mathrm{~kg})$ and then randomly assigned to one of the nine experimental units (3 treatments $\times 3$ replications). Each experimental unit (treatment $\mathrm{X}$ rep combination) was 0.27 ha and divided into four subpaddocks. Fifty-two lambs (Kathadin $\times$ Dorset) from the Center (initial weight $=26.2 \pm 3.05 \mathrm{~kg}$ ) were used for the study in 2009. All three replications were stocked with 6 lambs per experimental unit excluding the black walnut and honeylocust silvopastures in the second replicate. These pastures had reduced forage availability due to the needs of previous management (involving failed efforts at predator control). Thus, they were stocked with four lambs in 2008 and five lambs in 2009 as the pastures recovered from previous overgrazing. Each year, pastures were rotationally stocked from mid June through late September. In 2009, sub-paddocks were further divided with portable cross fencing to improve forage management. Due to concerns over coyote (Canis latrans) predation of sheep, lambs were moved to a central corral for safe housing each evening during the first 2 weeks of 2009. Two animals were lost from the analysis in 2009 due to coyote predation. Similar sized animals were used as replacements to maintain stocking rates among treatments. A third animal on trial was removed from the analysis due to a lack of response to anthelminthic treatment.

Forage mass

Each year of the study, pre- and post-graze forage heights were collected with each sub-paddock rotation by taking 30 random measures with a rising plate meter. At approximately two-week intervals, eighteen destructive samples of pre-graze and eighteen samples of post-graze forage (two pre- and two post-graze samples per experimental unit) were collected. The forage underneath the meter plate at resting height was marked by a quadrate and cut manually with shears. This material was dried at $55{ }^{\circ} \mathrm{C}$ in a forced draft oven for $48 \mathrm{~h}$ to determine dry matter (DM) concentration. Forage mass was sampled across a range of plate meter height readings and used to build a regression equation of mass relative to plate meter height. The relationship of mass to height was then used to determine pasture DM yield based on the average of plate meter heights within treatment pastures. The equation derived from this relationship, $\mathrm{DM}=1.0127 \mathrm{x}+4.8821$ $\left(\mathrm{r}^{2}=0.5064\right)$, was used for all pre- and post-graze forage mass calculations.

Forage nutritive value

Forage samples were collected every two weeks in the pre-graze pastures to determine nutritive value by 
treatment. Samples were harvested in the afternoon to limit differences in nutritive value due to diurnal variation (Holt and Hilst 1969). Dried forage samples $\left(55{ }^{\circ} \mathrm{C}\right.$ for $48 \mathrm{~h}$ ) were ground to pass a $1-\mathrm{mm}$ screen with a hammer mill. Neutral and acid detergent fiber (NDF and ADF) and acid detergent lignin (ADL) concentrations were determined sequentially using batch procedures. Forage nitrogen $(\mathrm{N})$ was determined using dry combustion procedures with a Vario MAX CNS macro-elemental analyzer (Elementar, Hanau, Germany) and forage crude protein (CP) was calculated as $N * 6.25$. All samples were analyzed in duplicate and the analysis was repeated if the coefficient of variation between duplicates exceeded 3\%.

Forage in vitro true digestibility (IVTD) was determined using an incubator and fiber analysis system (ANKOM Technology, Macedon, NY, USA). Rumen fluid collected for the IVTD assays came from a non-lactating Holstein cow fed a standard diet of firstcut, mixed, cool-season grass hay ad libitum plus $0.45 \mathrm{~kg}$ of cracked corn (Zea mays L.). The cow was fed once per day at approximately $0700 \mathrm{~h}$ and ruminal fluid was sampled at approximately $1300 \mathrm{~h}$. Samples were analyzed in duplicate and the analysis was repeated if the coefficient of variation between duplicates exceeded $4 \%$. Neutral detergent fiber digestibility (NDFD) was calculated from NDF and residual NDF (from IVTD measures) as $100 *(1-$ residual NDF, $\mathrm{g}) / \mathrm{NDF}, \mathrm{g}$.

Animal gain and carcass evaluation

Lambs were weighed on a platform with load cells using a digital scale. Lambs were weighed for two consecutive days prior to the study, then stratified and blocked by average weight and randomly assigned to experimental treatment. Once on trial, lambs were moved from pastures in the morning to a central corral for weighing. Lambs were treated with anthelminthic (fenbendazole) prior to grazing and at the end of each of three grazing periods. Weigh dates occurred at 32-day intervals during each season, except one 35-day interval (period 2) in 2008. At the conclusion of the study, lambs were weighed for two consecutive days, and the 2-day average weight for each lamb was used as its final weight. Total gain per system within each experimental unit was calculated as the sum of the lambs' final weights minus their initial weights.
Lamb ADG by period and season were calculated as gain divided by total grazing days within same.

Following the grazing study, the mean weight of lambs within an experimental unit (i.e., pasture) was calculated. Each year, the two lambs within an experimental unit whose weights were closest to the group mean were selected for carcass evaluation. Lambs $(\mathrm{n}=18)$ were supplied water and fasted overnight and then weighed before transport to the Virginia Tech Meats Lab. Following harvest, lamb hot carcass weights were recorded.

After a 24-h chill, carcasses were ribbed between the twelfth and thirteenth thoracic vertebrae and quality and yield grade data were collected. Bodywall thickness was measured $7.5 \mathrm{~cm}$ distal to the ventral end of the longissimus thoracic muscle. Back fat thickness was assessed by measuring three sites on the 12th rib using a metal ruler. Longissimus muscle area was measured with a plastic grid. A leg score for each lamb (defined as Prime, Choice, and Good) was determined by graders based upon muscling and coded by a number ranging with $15=$ Prime + to $7=$ Good-. Quality grade data were collected by an experienced evaluator in accordance with grading standards for young lambs (USDA 1992). Quality grade was coded by number for statistic analysis with $10=$ Choice-, $9=$ High Good, and $8=$ Low Good.

\section{Statistical analysis}

Experimental design was a randomized complete block with three replications. Experimental units within replicates included open pastures, black walnut silvopastures pastures, and honeylocust silvopastures. Forage yield and nutritive value and animal gain and carcass data were analyzed using repeated-measures mixed ANOVA with PROC MIXED of SAS, v. 9.2 (SAS Inst., Cary, NC). Year and period within year were the repeated measures used for the overall analysis and for within-year analyses, respectively. Compound symmetry covariance structure was used to analyze animal gain and forage nutritive value, while autoregressive covariance structure was used for forage mass data due to better fit statistics. Means separation was performed using Tukey's HSD. Differences were considered significant at $P<0.05$ and trends are reported, where appropriate, for $P<0.1$. 


\section{Results}

Forage botanical composition and mass

Visual observation of forage cover in pastures and silvopastures systems suggest tree species had unique effects on system ecology (Table 2). Open pastures were dominated by tall fescue, which also was more abundant in honeylocust than in black walnut silvopastures. Red clover presence was greatest $(P \leq 0.0031)$ in honeylocust silvopastures and intermediate in open pastures. Conversely, walnut silvopastures had more abundant $(P=0.0057)$ Kentucky bluegrass but also more $(P \leq 0.0085)$ broad leaf weeds and low-quality grasses such as sweet vernalgrass and nimblewill. Walnut systems also had more annuals than open pastures, as observed with greater $(P=0.0429)$ hop clover and non-significant $(P=0.1200)$ increases in cheatgrass.

Pre- and post-graze forage mass estimates varied by years, periods, and treatments and were affected by significant year $\times$ treatment interactions $(\mathrm{P}<0.05)$, thus, data are presented by measurement periods within year (Table 3 ). Pre-graze herbage mass did not differ $(P \geq 0.1355)$ among treatments (mean $=3490 \mathrm{~kg}$
$\mathrm{DM} / \mathrm{ha}$ ) at the start of the study in 2008. Pre-graze mass generally declined through subsequent grazing periods and was lower $(P \leq 0.0487)$ in black walnut silvopastures than in open pastures in mid- and latesummer measurement periods. Post-graze mass in 2008 generally was similar among treatments during early- and mid-summer grazing periods but walnut pastures had less $(P \leq 0.0119)$ residual forage than open and honeylocust systems in late summer (midAugust to mid-September). In addition, average herbage disappearance (i.e., over the entire season) was greater $(P \leq 0.0316)$ from within the open systems than the silvopastures.

Pre-graze forage mass was greater in 2009 than in 2008 (Table 1), and the open system had greater pregraze forage mass than black walnut $(P \leq 0.0045)$ and honeylocust $(P \leq 0.0735)$ silvopastures at all measurement periods. Averaged over the entire summer, herbage mass in the honeylocust silvopasture was greater $(P=0.0487)$ than in the black walnut silvopasture. Post-graze mass followed a similar pattern. Open systems had greater $(P \leq 0.0123)$ residual forage mass than black walnut silvopastures during each grazing period and greater forage mass than honeylocust systems during the late summer

Table 2 Visual estimates of botanical composition in open $(\mathrm{O})$ pasture and black walnut (BW) and honeylocust (HL) silvopastures before the grazing season in 2009

\begin{tabular}{|c|c|c|c|c|c|c|c|}
\hline \multirow[t]{2}{*}{ Species $^{\mathrm{a}}$} & \multicolumn{3}{|c|}{ Score } & \multirow[t]{2}{*}{ SE } & \multicolumn{3}{|c|}{ Tukey's adjusted P } \\
\hline & $\mathrm{O}$ & $\mathrm{BW}$ & $\mathrm{HL}$ & & O vs. BW & $\mathrm{O}$ vs. HL & BW vs. HL \\
\hline Tall fescue & 5.00 & 4.00 & 4.50 & 0.11 & $<0.0001$ & 0.0003 & 0.0003 \\
\hline Kentucky bluegrass & 2.83 & 4.08 & 2.78 & 0.37 & 0.0057 & 1.0000 & 0.0057 \\
\hline Orchardgrass & 2.92 & 2.67 & 2.92 & 0.27 & 0.6374 & 0.6374 & 1.0000 \\
\hline White clover & 0.75 & 1.50 & 0.83 & 0.46 & 0.2441 & 0.9819 & 0.3244 \\
\hline Red clover & 2.17 & 0.83 & 3.41 & 0.35 & 0.0016 & 0.0031 & $<0.0001$ \\
\hline Broad leaf weeds & 0.17 & 1.17 & 0.25 & 0.29 & 0.0040 & 0.9543 & 0.0085 \\
\hline Sweet vernalgrass & 0.00 & 0.42 & 0.00 & 0.12 & 0.0044 & 1.000 & 0.0044 \\
\hline Nimblewill & 0.00 & 0.42 & 0.00 & 0.12 & 0.0044 & 1.000 & 0.0044 \\
\hline Hop clover & 0.17 & 0.92 & 0.42 & 0.30 & 0.0429 & 0.9806 & 0.2271 \\
\hline Honeylocust & 0.00 & 0.00 & 0.17 & 0.14 & 1.0000 & 0.4479 & 0.4479 \\
\hline Cheatgrass & 0.00 & 0.50 & 0.08 & 0.25 & 0.1200 & 0.9385 & 0.2218 \\
\hline Quackgrass & 0.17 & 0.00 & 0.58 & 0.25 & 0.7916 & 0.2465 & 0.0724 \\
\hline
\end{tabular}

Composition estimates were based on a 5-point scale. Scoring for the 5-point scale: Dominant $=5$; Abundant $=4$; Frequent $=3$; Observed $=2$; Rare $=1$

${ }^{\mathrm{a}}$ Tall fescue (Schedonorus phoenix); Kentucky bluegrass (Poa perenne); Orchardgrasss (Dactlis glomerata); White clover (Trifolium repens); Red clover (T. pretense); Sweet vernalgrass (Anthoxantum oderatum); Nimblewill (Muhlenbergia schreberi); Hop clover (T. campestre); Honeylocust (Gleditsia triacanthos); Cheatgrass (Bromus tectorum); Quackgrass (Elymus repens) 
Table 3 Pre- and postgraze forage mass and herbage disappearance (difference) among open (O) pasture and black walnut (BW) and honeylocust (HL) silvopastures in 2008 and 2009
${ }^{a}$ Early-, mid- and lateseason grazing periods were from approximately midJune to mid-July, mid-July to mid-August, and midAugust to mid-September

\begin{tabular}{|c|c|c|c|c|c|c|c|}
\hline \multirow[t]{2}{*}{ Year and period ${ }^{\mathrm{a}}$} & \multicolumn{3}{|c|}{$\mathrm{kg} \mathrm{DM} \mathrm{ha}^{-1}$} & \multirow[t]{2}{*}{ SE } & \multicolumn{3}{|c|}{ Tukey's adjusted P } \\
\hline & $\mathrm{O}$ & BW & $\mathrm{HL}$ & & $\mathrm{O}$ vs. BW & $\mathrm{O}$ vs. HL & BW vs. HL \\
\hline \multicolumn{8}{|l|}{2008} \\
\hline \multicolumn{8}{|l|}{ Pre-graze } \\
\hline Early & 3690 & 3280 & 3500 & 207 & 0.1355 & 0.6354 & 0.5412 \\
\hline Mid & 3340 & 2800 & 3020 & 217 & 0.0487 & 0.3215 & 0.5693 \\
\hline Late & 2750 & 2220 & 2480 & 196 & 0.0323 & 0.3742 & 0.3989 \\
\hline Average & 3260 & 2770 & 3000 & 123 & 0.0003 & 0.0937 & 0.1426 \\
\hline \multicolumn{8}{|l|}{ Post-graze } \\
\hline Early & 2380 & 2150 & 2320 & 102 & 0.0912 & 0.8275 & 0.2624 \\
\hline Mid & 2120 & 1960 & 2170 & 142 & 0.5190 & 0.9324 & 0.3245 \\
\hline Late & 1980 & 1670 & 1910 & 56 & 0.0015 & 0.6952 & 0.0119 \\
\hline Average & 2160 & 1930 & 2130 & 68 & 0.0030 & 0.9305 & 0.0091 \\
\hline \multicolumn{8}{|l|}{ Difference } \\
\hline Early & 1320 & 1130 & 1190 & 180 & 0.5606 & 0.7554 & 0.9454 \\
\hline Mid & 1220 & 840 & 850 & 135 & 0.0224 & 0.0281 & 0.9946 \\
\hline Late & 770 & 560 & 570 & 151 & 0.3451 & 0.3846 & 0.9967 \\
\hline Average & 1100 & 840 & 870 & 91 & 0.0140 & 0.0316 & 0.9511 \\
\hline \multicolumn{8}{|l|}{2009} \\
\hline \multicolumn{8}{|l|}{ Pre-graze } \\
\hline Early & 4650 & 3720 & 4030 & 272 & 0.0045 & 0.0735 & 0.4970 \\
\hline Mid & 3820 & 2880 & 3280 & 207 & 0.0002 & 0.0335 & 0.1527 \\
\hline Late & 2760 & 2150 & 2330 & 118 & $<0.0001$ & 0.0031 & 0.2883 \\
\hline Average & 3740 & 2920 & 3210 & 124 & $<0.0001$ & 0.0001 & 0.0487 \\
\hline \multicolumn{8}{|l|}{ Post-graze } \\
\hline Early & 2780 & 2370 & 2500 & 96 & 0.0123 & 0.1047 & 0.6246 \\
\hline Mid & 2430 & 1780 & 2100 & 127 & 0.0027 & 0.1844 & 0.1832 \\
\hline Late & 2060 & 1590 & 1700 & 70 & 0.0002 & 0.0032 & 0.5450 \\
\hline Average & 2420 & 1910 & 2100 & 85 & $<0.0001$ & 0.0006 & 0.0764 \\
\hline \multicolumn{8}{|l|}{ Difference } \\
\hline Early & 1860 & 1350 & 1530 & 256 & 0.1252 & 0.4086 & 0.7569 \\
\hline Mid & 1390 & 1110 & 1180 & 163 & 0.1914 & 0.3788 & 0.9088 \\
\hline Late & 700 & 560 & 630 & 113 & 0.6355 & 0.9017 & 0.8807 \\
\hline Average & 1320 & 1000 & 1110 & 116 & 0.0196 & 0.1789 & 0.6100 \\
\hline
\end{tabular}

$(P=0.0032)$ and for the seasonal average $(P=0.0006)$. Differences in pre- and post-graze herbage mass were not significant at individual measurement periods but were greater $(P=0.0196)$ in open pastures than in black walnut silvopastures averaged over the 2009 season.

Forage nutritive value and digestibility

Data for forage nutritive value were similar between years and largely unaffected by treatment $x$ year interactions; thus, data are presented over years (Table 4). Differences among treatments and grazing periods during the study largely were limited to NDF and hemicellulose measures. Forage NDF concentrations in black walnut silvopastures were about $50 \mathrm{~g} / \mathrm{kg}$ greater $(P \leq 0.0003)$ than in both other systems during the early summer grazing period and greater $(P=0.0105)$ than in the open pasture in mid-summer. Differences in ADF concentrations only were observed in the early summer grazing period, when pastures in the walnut system had greater 
Table 4 Nutritive value and digestibility characteristics of forages grown in open $(\mathrm{O})$ pastures and black walnut (BW) and honeylocust (HL) silvopastures
Values represent averages by period ${ }^{\mathrm{a}}$ from treatment pastures grazed by sheep in 2008 and 2009

NDF Neutral detergent fiber, $A D F$ acid detergent fiber, Hemi hemicellulose, $A D L$ acid detergent lignin, $C P$ crude protein, IVTD in vitro true digestibility, NDFD neutral detergent fiber digestibility

${ }^{\mathrm{a}}$ Early = mid-June to midJuly; Mid = mid-July to mid-August; Late $=$ midAugust to mid-September

${ }^{\mathrm{b}}$ Period effects were significant for all responses except $\mathrm{CP}$ and NDFD

\begin{tabular}{|c|c|c|c|c|c|c|c|c|}
\hline \multirow[t]{2}{*}{ Item } & \multirow[t]{2}{*}{ Period $^{\mathrm{b}}$} & \multicolumn{3}{|c|}{$\mathrm{g} \mathrm{kg}^{-1}$ of dry matter } & \multirow[t]{2}{*}{ SE } & \multicolumn{3}{|c|}{ Tukey's adjusted P } \\
\hline & & $\mathrm{O}$ & BW & HL & & O vs. BW & $\mathrm{O}$ vs. HL & BW vs. HL \\
\hline \multirow[t]{4}{*}{ NDF } & Early & 499 & 550 & 499 & 12 & 0.0002 & 0.9993 & 0.0003 \\
\hline & Mid & 484 & 529 & 505 & 14 & 0.0105 & 0.3313 & 0.2009 \\
\hline & Late & 531 & 557 & 542 & 15 & 0.2005 & 0.7331 & 0.5790 \\
\hline & Average & 507 & 518 & 516 & 13 & 0.0463 & 0.7647 & 0.1141 \\
\hline \multirow[t]{4}{*}{ ADF } & Early & 263 & 282 & 266 & 8 & 0.0415 & 0.8922 & 0.1217 \\
\hline & Mid & 255 & 268 & 269 & 9 & 0.3182 & 0.2804 & 0.9959 \\
\hline & Late & 268 & 278 & 266 & 10 & 0.6213 & 0.9716 & 0.4766 \\
\hline & Average & 263 & 278 & 267 & 7 & 0.1846 & 0.8358 & 0.3761 \\
\hline \multirow[t]{4}{*}{ Hemi } & Early & 236 & 269 & 233 & 8 & 0.0009 & 0.9304 & 0.0003 \\
\hline & Mid & 228 & 261 & 235 & 10 & 0.0073 & 0.7480 & 0.0342 \\
\hline & Late & 262 & 279 & 276 & 8 & 0.1285 & 0.2601 & 0.9162 \\
\hline & Average & 243 & 270 & 249 & 8 & 0.0456 & 0.8159 & 0.0987 \\
\hline \multirow[t]{4}{*}{ ADL } & Early & 34 & 36 & 33 & 4 & 0.8492 & 0.9147 & 0.6185 \\
\hline & Mid & 30 & 32 & 32 & 4 & 0.9146 & 0.8753 & 0.9953 \\
\hline & Late & 28 & 33 & 30 & 4 & 0.4815 & 0.8449 & 0.8131 \\
\hline & Average & 31 & 34 & 32 & 1 & 0.0887 & 0.7252 & 0.2464 \\
\hline \multirow[t]{4}{*}{$\mathrm{CP}$} & Early & 121 & 127 & 120 & 6 & 0.5498 & 0.9893 & 0.4755 \\
\hline & Mid & 131 & 127 & 130 & 5 & 0.7616 & 0.9903 & 0.8268 \\
\hline & Late & 129 & 127 & 126 & 5 & 0.9572 & 0.8744 & 0.9750 \\
\hline & Average & 126 & 127 & 125 & 4 & 0.9455 & 0.9726 & 0.8523 \\
\hline \multirow[t]{4}{*}{ IVTD } & Early & 739 & 744 & 726 & 15 & 0.9476 & 0.6639 & 0.4745 \\
\hline & Mid & 742 & 743 & 745 & 15 & 0.9983 & 0.9729 & 0.9838 \\
\hline & Late & 729 & 703 & 729 & 20 & 0.3770 & 0.9999 & 0.3790 \\
\hline & Average & 736 & 728 & 730 & 13 & 0.8289 & 0.8907 & 0.9910 \\
\hline \multirow[t]{4}{*}{ NDFD } & Early & 498 & 548 & 465 & 33 & 0.2741 & 0.5904 & 0.0403 \\
\hline & Mid & 483 & 532 & 512 & 37 & 0.3995 & 0.7153 & 0.8499 \\
\hline & Late & 508 & 482 & 518 & 33 & 0.7119 & 0.9453 & 0.5101 \\
\hline & Average & 497 & 520 & 492 & 28 & 0.7059 & 0.9845 & 0.6103 \\
\hline
\end{tabular}

$(P=0.0415)$ fiber levels. The generally greater NDF and limited effects on ADF resulted in walnut silvopastures resulted in greater $(P \leq 0.0456)$ hemicellulose (about $30 \mathrm{~g} / \mathrm{kg}$ ) during early- and midsummer and averaged over the grazing seasons. Acid detergent lignin also tended $(P=0.0887)$ to be greater in the walnut silvopasture over the season. Forage protein concentrations over years averaged $126 \mathrm{~g} / \mathrm{kg}$ and were not affected $(P \geq 0.4755)$ by treatment during any period. Similarly, IVTD and NDFD were largely unaffected by silvopasture treatment. The only observed measure of difference was greater $(P=0.0403)$ NDFD in early summer in the forages from walnut silvopasture relative to those from the honeylocust system.
Observed differences in ADL were very limited, and this was unexpected. Greater ADL concentrations have been observed in low light environments due to increases in internodal tissues which contain higher levels of lignin (Allard et al. 1991). However, the low ADL concentrations and the variability associated with the third stage of a sequential analysis may have limited the sensitivity of this assay.

Although equal or greater levels of CP have been observed in shaded forages both in laboratory and field studies (Kephart and Buxton 1993; Kallenbach et al. 2006), differences due to tree shade have been limited in other studies at this location (Buergler et al. 2006). Greater CP levels in forages grown in honeylocust silvopastures observed by Buergler et al. (2006) were 
attributed to higher levels of clover than in black walnut silvopastures. The lack of differences in forage $\mathrm{CP}$ observed here occurred despite lower levels of red clover in the walnut silvopastures (Table 2). Given the older, larger trees in this study, shading likely was greater than in the work by Buergler et al. (2006). Thus-at least in the in the case of black walnut silvopastures - greater shading may have elevated $\mathrm{N}$ in forage grasses, which would have compensated for the lower level of legumes in these systems.

Animal gain

Lamb ADG in response to treatment differed by year (treatment $\times$ year interaction; $P=0.0109$ ) and period within years $(P<0.0001)$ and thus data are presented by period for each grazing season (Table 5). In 2008, ADG did not differ by treatment over the season (Table 5), although gains tended $(P=0.0970)$ to be greater in honeylocust than in black walnut silvopasture systems in late summer. Gains did not differ by system in early- and mid-summer grazing periods in 2009. Despite lower stocking rates for some silvopastures, total gain among pastures and silvopastures were not different $(P \geq 0.7941)$ in 2008 and there were no differences between open pasture and honeylocust silvopastures in 2009.
Carcass evaluation

Live weights of lambs selected for carcass evaluation did not differ among treatments (Table 6). No carcass attributes (backfat thickness, body wall, longissimus muscle area, leg score, and quality grade) were affected by treatment $(\mathrm{P} \geq 0.1762)$. Quality grades for all treatments averaged 'good' (USDA 1992).

\section{Discussion}

Forage botanical composition and mass

Although botanical composition was not measured at the time of forage establishment in the mid-1990s, the stand at establishment was uniform across the site and unlikely to have differed among treatments more than 10 years later is simply due to random probability. Evidence of differences in understory vegetation due to tree species have been both observed empirically and reported systematically (Buergler et al. 2005) at earlier stages of silvopasture development. We acknowledge that the picture of how tree presence changes the system understorys is limited given that the values presented here were from a single point-intime estimate in late spring before the grazing season.
Table 5 Average daily gain and total gain of crossbred hair sheep lambs grazing in open $(\mathrm{O})$ pasture and black walnut (BW) and honeylocust (HL) silvopasture treatments in 2008 and 2009

${ }^{\mathrm{a}}$ Grazing trials were divided into early, mid- and late season periods which were from approximately midJune to mid-July, mid-July to mid-August, and midAugust to mid-September

\begin{tabular}{|c|c|c|c|c|c|c|c|}
\hline \multirow[t]{2}{*}{ Year and period ${ }^{\mathrm{a}}$} & \multicolumn{3}{|l|}{ g/day } & \multirow[t]{2}{*}{ SE } & \multicolumn{3}{|c|}{ Tukey's adjusted P } \\
\hline & $\mathrm{O}$ & BW & $\mathrm{HL}$ & & O vs. BW & $\mathrm{O}$ vs. HL & BW vs. HL \\
\hline \multicolumn{8}{|l|}{2008} \\
\hline Early & 111 & 132 & 133 & 16.9 & 0.4261 & 0.3911 & 0.9979 \\
\hline Mid & 105 & 113 & 107 & 12.3 & 0.7962 & 0.9931 & 0.8623 \\
\hline Late & 33 & 24 & 45 & 9.9 & 0.6185 & 0.4356 & 0.0970 \\
\hline Average & 84 & 91 & 96 & 11.0 & 0.5839 & 0.2298 & 0.7915 \\
\hline \multicolumn{8}{|l|}{2009} \\
\hline Early & 15 & 25 & 49 & 17.6 & 0.8479 & 0.1321 & 0.3613 \\
\hline Mid & 126 & 109 & 114 & 10.8 & 0.2445 & 0.4890 & 0.8884 \\
\hline Late & 76 & 7 & 72 & 16.1 & 0.0002 & 0.9726 & 0.0007 \\
\hline Average & 72 & 41 & 78 & 9.5 & 0.0051 & 0.7979 & 0.0011 \\
\hline \multirow[t]{2}{*}{ Year and period $^{\mathrm{a}}$} & \multicolumn{3}{|l|}{$\mathrm{kg}$} & SE & \multicolumn{3}{|c|}{ Tukey's adjusted P } \\
\hline & $\mathrm{O}$ & BW & HL & & $\mathrm{O}$ vs. $\mathrm{BW}$ & $\mathrm{O}$ vs. HL & BW vs. HL \\
\hline \multicolumn{8}{|l|}{ Total gain } \\
\hline 2008 & 49.8 & 46.8 & 49.3 & 4.60 & 0.7941 & 0.9943 & 0.8463 \\
\hline 2009 & 41.6 & 22.5 & 42.6 & 6.27 & 0.0764 & 0.9895 & 0.0642 \\
\hline
\end{tabular}


Table 6 Carcass characteristics of lambs that grazed open pastures (O) and black walnut (BW) and honeylocust (HL) silvopasture treatments in 2008 and 2009

\begin{tabular}{|c|c|c|c|c|c|c|c|}
\hline \multirow[t]{2}{*}{ Carcass trait } & \multirow[t]{2}{*}{$\mathrm{O}$} & \multirow[t]{2}{*}{ BW } & \multirow[t]{2}{*}{ HL } & \multirow[t]{2}{*}{ SE } & \multicolumn{3}{|c|}{ Tukey's adjusted P } \\
\hline & & & & & $\mathrm{O}$ vs. BW & $\mathrm{O}$ vs. HL & BW vs. HL \\
\hline Live Weight (kg) & 32.5 & 31.8 & 33.4 & 0.96 & 0.7452 & 0.6785 & 0.3098 \\
\hline Hot Carcass (kg) & 16.2 & 14.8 & 16.4 & 0.40 & 0.0376 & 0.8048 & 0.0189 \\
\hline Backfat (mm) & 1.57 & 1.60 & 1.23 & 0.24 & 0.9900 & 0.3961 & 0.3503 \\
\hline Bodywall (mm) & 9.11 & 8.42 & 8.89 & 0.74 & 0.6465 & 0.9548 & 0.8054 \\
\hline Longissimus area $\left(\mathrm{cm}^{2}\right)$ & 10.27 & 9.49 & 10.22 & 0.66 & 0.5085 & 0.9963 & 0.5514 \\
\hline Leg score & 9.67 & 9.45 & 9.5 & 0.21 & 0.6466 & 0.7080 & 0.9871 \\
\hline Quality grade & 9.25 & 8.73 & 9.08 & 0.23 & 0.1732 & 0.7584 & 0.3845 \\
\hline
\end{tabular}

For example, the presence of cheatgrass, a cool season annual, was on the wane when measured, because this species had nearly completed its life cycle. Conversely, the presence of nimblewill was likely underrepresented because it was too early in the season for this warm-season perennial to be fully actively growing.

Greater pre-graze forage mass in 2009 than in 2008 likely occurred due to greater precipitation before the grazing season and moderate temperatures over the summer (Table 1). Averaged over the two years, conditions in the walnut and honeylocust systems lowered pre-graze forage mass about 19 and $11 \%$, respectively, as compared with open pasture forage mass. Similar forage mass reductions were reported in a spring grazing study that compared a mixed pine/ walnut-based silvopasture with open pastures (Kallenbach et al. 2006). However, the pine trees and greater total number of trees per area in that experiment would be expected to create a more shaded environment and consequently have reduced forage yield. The large decline in pre-graze forage mass from period 2 to period 3 of 2009 was unanticipated and may in part be a function of reduced available solar radiation to the systems (Table 1) over the season. Lower insolation, coupled with shading from trees likely compromised forage productivity in the silvopasture systems. This highlights the critical role of light (and thus tree) management to maintain forage production in silvopastures.

Greater reductions in pre- and post-graze forage mass in black walnut silvopastures relative to other systems likely reflects greater competition due to differences in tree morphology and chemical ecology. Although not measured in this study, other data from these sites (e.g., Buergler 2004) indicate shade from walnut canopies is denser than honeylocust shade.
Allelopathy may be another factor in reduced forage production in walnut-based systems. Although fescue demonstrates little sensitivity to walnut trees (Appleton et al. 2009) and walnut husks did not affect orchardgrass or red clover in a study by Houx et al. (2008), the chemical agent of walnut allelopathy, juglone, is known to affect dicot species including alfalfa and clovers (Davis 1928; Rietveld 1983). Along with these results, we have observed reduced clover presence in prior studies from this site (Buergler et al. 2005). Although the mechanisms were not explored here, it is likely that some combination of shade and allelopathy drove the observed differences in botanical composition and production within the walnut silvopastures. Perhaps the negative effect of walnuts on legume presence reduces the production and cover of more desirable cool season grass growth by decreasing available $\mathrm{N}$ to the forage system, but this hypothesis remains to be explored.

Forage nutritive value and digestibility

Limited differences in forage nutritive entities were somewhat unexpected given other reports of response to shade (e.g., Kallenbach et al. 2006; Neel et al. 2015). Reduced NDF occurs as a function of lower growing temperatures (Kephart and Buxton 1993), and equal or lower NDF and ADF levels were reported in pine/black walnut silvopastures compared with open pastures (Kallenbach et al. 2006). Although not measured, ambient temperatures in both silvopasture systems were noticeably lower under trees. Given the empirically-observed differences in environmental conditions, it is likely that the higher NDF concentrations in black walnut silvopastures reflect botanical composition differences, particularly the greater 
amounts of nimblewill and lower levels of red clover (Table 2).

Similar results for forage ADF were reported by Lin et al. (2001), who tested forages grown under shade cloth. Those authors reported that ADF levels were unaffected by increased shade. In contrast, equal or lower ADF levels were reported in annual forage species in pine-black walnut silvopastures (Kallenbach et al. 2006), while others have found higher forage fiber concentrations in silvopastures created in thinned woodlands (Neel et al. 2015). It is unclear the degree to which shading and temperature reductions drove these different observations. Lin et al. (2001) conducted their study in summer with perennial forages whereas Kallenbach et al. (2006) researched cool-season annual forage production in spring. Neel et al. (2015) compared nutritional responses in perennial forages at morphological maturity over a grazing season and reported greater fiber concentrations in silvopasture systems, although morphological maturity was delayed.

\section{Animal gain}

Much lower ADG in this final period of 2008 reflect lower precipitation (Table 1) and available forage (Table 2) for all systems. Low ADG for all systems in early summer 2009 appear to be a function of corralling animals each evening for the first two weeks of the study to avoid coyote predation. The decline in animal gains on black walnut silvopastures in the late season may reflect greater amounts of nimblewill and broadleaf weeds-particularly stickweed (Verbesina occidentalis). These species generally are not preferred by lambs and their presence would have contributed to lower intake and ADG. Forage production in these systems also was substantially lower. In addition, gains for lambs in one replicate black walnut silvopasture were much lower than average (rep effect; $P<0.0001$ ). Lambs from this replicate likely were subject to parasite challenge, and one animal from this treatment was removed from the analysis given lack of response to anthelminthic treatment. Effects both of parasites and predators limit our capacity to fully interpret the effects of silvopastures on animal gain, but the evidence is clear based on data from the honeylocust system that animal gain and total system output can be equal to open pastures with silvopasture systems and this is before accounting any value of the trees.

Towards the end of both grazing seasons, some seedpods dropped in the honeylocust systems and were readily consumed by sheep in those systems. Honeylocust pods have excellent feed value (e.g., see Johnson et al. 2012, 2013) and may be useful as a supplement for small ruminants. Our unpublished data from this environment indicate animal performance on honeylocust pods can be quite high if animals are not naïve to the pods. However, in this study most pods dropped well after the end of this study and thus likely contributed little to animal gains in this study.

These production data are similar to those of Kallenbach et al. (2006) who reported no differences in ADG between open pastures and silvopastures grazed by crossbred beef heifers despite lower levels of forage production. That ADG was similar for all treatments in 2008 suggests that black walnut-based silvopasture systems can be as productive as open systems. However, using these trees likely will require greater management in order to maintain levels of light and legumes capable of supporting suitable botanical composition and forage production.

\section{Carcass evaluation}

This is likely because lambs selected for carcass evaluation were closest to the mean body weight of each experimental unit at the end of the grazing trial. However, the lower $(P \leq 0.0376)$ hot carcass weights of animals that grazed black walnut silvopastures suggest that these animals may have had greater visceral organ mass, greater gastro-intestinal fill, or both. Although among experimental treatments, statistical differences for forage fibers, lignin, and digestibility were limited or not observed in late summer, the numeric patterns would agree with our interpretation of greater intestinal fill.

Although lower than commonly desired for retail markets, quality grades were typical for pasture-fed lambs without supplements, particularly for hair sheep. Greater quality grades than reported here have been observed when Katahdin lambs were fed high protein diets (Burke et al. 2003). Potential value of honeylocust pods as a supplement for livestock on pastures will require further study. 


\section{Conclusions}

Honeylocust silvopastures supported animal output similar to open pastures, and these systems show great promise for temperate hardwood silvopastures in the Appalachian region. Forage production and nutritive value were similar to open pastures allowing for similar animal output. Black walnut silvopasture systems performed well in 2008 with similar animal production despite somewhat lower forage yields. Animal performance in black walnut silvopastures was less than from control pastures in 2009. Forage species were less desirable and forage availability likely was challenged by weed pressure. Performance of these lambs also may have been compromised by parasitic nematodes. Changes in forage species contained in black walnut silvopastures was likely a contributing factor. Further research on tree management and suitable forage species for black walnut silvopastures may be useful for improving forage productivity of these systems relative to open pasture and other silvopastures.

Over two seasons, summer lamb gains averaged about $83 \mathrm{~g} /$ day for animals in open and honeylocust silvopastures compared with $66 \mathrm{~g} /$ day for lambs in black walnut systems. Walnut systems supported lower hot carcass weights, but carcass quality did not differ from open pastures in these intermediate-stage hardwood silvopasture systems. Further research will be needed to understand system performance at final tree densities. The economic performancce of these systems also needs evaluation based on labor inputs (tree establishment and maintenance) and economic outputs (livestock, timber, nuts, and pods) along with measures of associated environmental impacts.

\section{References}

Allard G, Nelson CJ, Pallardy SG (1991) Shade effects on growth of tall fescue: I. Leaf anatomy and dry matter partitioning. Crop Sci 31:163-167

Appleton B, Berrier R, Harris R, Alleman D, Swanson L (2009) The walnut tree: allelopathic effects and tolerant plants. Virginia Cooperative Extension Publication 430-021

Brodie J (1985) Vegetation anaylsis. In: Grassland studies. Unwin Hyman, Boston

Buergler AL (2004) Forage production and nutritive value in a temperate Appalachian silvopasture. M.S. Thesis, Virginia Polytechnic Institute and State University
Buergler AL, Fike JH, Burger JA, Feldhake CR, McKenna JA, Teutsch CD (2005) Botanical composition and forage production in an emulated silvopasture. Agron J 97:1141-1147

Buergler AL, Fike JH, Burger JA, Feldhake CR, McKenna JA, Teutsch CD (2006) Forage nutritive value in an emulated silvopasture. Agron J 98:1265-1273

Burke JM, Apple JK, Roberts WJ, Boger CB, Kegley EB (2003) Effect of breed-type on performance and carcass traits of intensively managed hair sheep. Meat Sci 63:309-315

Burner DM, Brauer DK (2003) Herbage response to spacing of loblolly pine trees in a minimal management silvopasture in southeastern USA. Agrofor Syst 57:67-75

Clason TR, Sharrow SH (2000) Silvopastoral practices. In: Garrett HE, Rietveld WJ, Fisher RF (eds) North American agroforestry: an integrated science and practice. American Society of Agronomy, Inc., Madison, WI, pp 79-118

Davis EF (1928) The toxic principle of Juglans nigra as identified with synthetic juglone, and its effects on tomato and alfalfa plants. Am J Bot 15:620

Debruyne SA, Burger JA, Feldhake CM, Fike JH (2011) Tree effects on forage growth and soil water in an Appalachian silvopasture. Agrofor Syst 83:189-200

Feldhake CM, Schumann CM (2005) Tree establishment for a temperate agro-forest in Central Appalachia, USA. Agrofor Syst 65:187-195

Fike JH, Buergler AL, Burger JA, Kallenbach RL (2004) Considerations for establishing and managing silvopastures. Forage Grazinglands. https://doi.org/10.1094/FG-20041209-01-RV

Ford MM, Zamora DS, Current D, Magner J, Wyatt G, Walter WD, Vaughan S (2017) Impact of managed woodland grazing on forage quantity, quality and livestock performance: the potential for silvopasture in Central Minnesota, USA. Agrofor Syst. https://doi.org/10.1007/s10457-0170098-1

Holt DA, Hilst AR (1969) Daily variation in carbohydrate content of selected forage crops. Agron J 61:239-242

Houx JH, Garrett HE, McGraw JL (2008) Applications of black walnut husks can improve orchardgrass and red clover yields in silvopasture and alley cropping plantings. Agrofor Syst 73:181-187

Johnson JW, Fike JH, Fike WB, Burger JA, Munsell JF, McKenna JR, Hodges SC (2012) Millwood and wild type honeylocust seedpod nutritive value changes over winter. Crop Sci 52:2807-2816

Johnson JW, Fike JH, Fike WB, Burger JA, McKenna JR, Munsell JF, Hodges SC (2013) Millwood honeylocust trees: seedpod nutritive value and yield characteristics. Agrofor Syst 87:849-856

Kallenbach RL, Kerley MS, Bishop-Hurley GJ (2006) Cumulative forage production, forage quality and livestock performance from an annual ryegrass and cereal rye mixture in a Pine-Walnut Silvopasture. Agrofor Syst 66:43-53

Kallenbach RL, Venable EB, Kerley MS, Bailey NJ (2010) Stockpiled tall fescue and livestock performance in an early stage midwest silvopasture system. Agrofor Syst 80:379-384

Kephart KD, Buxton DR (1993) Forage quality responses of C3 and $\mathrm{C} 4$ perennial grasses to shade. Crop Sci 33:831-837 
Lin CH, McGraw RL, George MF, Garrett HE (2001) Nutritive quality and morphological development under partial shade of some forage species with agroforestry potential. Agrofor Syst 53:269-281

Mayerfeld D, Rickenbach M, Rissma A (2016) Overcoming history: attitudes of resource professionals and farmers toward silvopasture in southwest Wisconsin. Agrofor Syst 90:723-736

McArthur AJ (1991) Forestry and shelter for livestock. For Ecol Mgt 45:93-107

McDaniel AH, Roark CB (1956) Performance and grazing habits of Hereford and Aberdeen-angus cows and calves on improved pastures as related to types of shade. J Anim Sci 15:59-63

Mitlöhner FM, Galyean ML, McGlone JJ (2002) Shade effects on performance, carcass traits, physiology, and behavior of heat-stressed feedlot heifers. J Anim Sci 80:2043-2050

Mize TA (2014) Perceptions and understanding of silvopasture by extension agents in the Mid-Atlantic and Southern United States. Report to the faculty of Virginia Polytechnic Institute and State University, Non-thesis MS

Neel JPS, Belesky DP (2015) Herbage production, nutritive value and animal productivity within hardwood silvopasture, open and mixed pasture systems in Appalachia, United States. Grass For Sci 72:137-153

Neel JPS, Felton EED, Singh S, Sexstone AJ, Belesky DP (2015) Open pasture, silvopasture and sward herbage maturity effects on nutritive value and fermentation characteristics of cool-season pasture. Grass For Sci 71:259-269

Orefice J, Smith RG, Carroll J, Asbjornsen H, Howard T (2016) Forage productivity and profitability in newly-established open pasture, silvopasture, and thinned forest production systems. Agrofor Syst. https://doi.org/10.1007/s10457016-0052-7

Orefice JJ, Carroll D Conroy, Ketner L (2017) Silvopasture practices and perspectives in the Northeastern United States. Agrofor Syst 91:149-160

Peri PL, Varella AC, Lucas RJ, Moot DJ (2001) Cocksfoot and lucerne productivity in a Pinus radiata silvopastoral system: a grazed comparison. Proc NZ Grassl Assn 63:139-147

Rietveld WJ (1983) Allelopathic effects of juglone on germination and growth of several herbaceous and woody species. J Chem Ecol 9:295-308

USDA (1992) United States standards for grades of lamb, yearling mutton, and mutton carcasses. Agricultural Marketing Service, United States Department of Agriculture, Washington, DC

Wildeus S (1997) Hair sheep genetic resources and their contribution to diversified small ruminant production in the United States. J Anim Sci 75:630-640 